\title{
Peace and National Development in Nigeria: The Rivers State Experience
}

\author{
EMMANUEL I. WONAH
}

\section{DEPARTMENT OF POLITICAL AND ADMINISTRATIVE STUDIES, FACULTY OF SOCIAL SCIENCES, UNIVERSITY OF PORT HARCOURT. P.M.B 5323. PORT HARCOURT}

\begin{abstract}
The paper examined Peace and National Development in Nigeria: The Rivers State Experience. The paper argued that whereas peace is a sine qua non for National Development, the nature and character of Nigerian state has exacerbated conflict which threatens peace and national development in Nigeria and Rivers State in particular. The Marxian Political Economy and the Frustration-Aggression theory $(F-A)$ were used as analytical constructs. One of the major assumptions of the Marxian Political Economy is that society is divided into two classes - those who own the means of production (Bourgeoisie) and those who do not own the means of production (Proletariats). The Bourgeoisie exploit the proletariats by appropriating the surplus value generated from a social production. For Frustration-Aggression theory, frustration leads to aggression. The paper relied on secondary sources of data and the paper noted that there are unresolved, destructive and seemingly perennial conflicts which encumber peace and national development in Nigeria and Rivers State. The paper recommended inter alia, that democratic institutions should not only be strengthened, but also democratic culture should be imbibed and demonstrated by Nigerians, particularly the political elites in Nigeria.
\end{abstract}

Key words: Peace, National Development; Conflict; Nigerian State.

DOI: $10.7176 / \mathrm{DCS} / 9-9-08$

Publication date:September $30^{\text {th }} 2019$

\section{INTRODUCTION}

It is axiomatic that no two persons are exactly the same, not even identical twins. This means that different persons have different tastes and preferences which are exemplified in their different interests. A time comes when these interests can clash and if not checkmated can degenerate to conflict. Thus, conflict is natural but what really matters is how conflict is resolved. Nature has placed some inadequacies on man. Consequently, man loves living in a community with his fellow man as a social animal. However, it appears, the more centripetal forces pull man together, the more centrifugal forces pull them apart. This paradox unfortunately plunges man into the Hobbesian state of nature where life is short, nasty and brutish. The need to harmonize the ever conflicting interests of man and ensure that man achieves self and collective actualization in a just, mutually beneficial, conducive, egalitarian and peaceful society validates the emergence of state. In tandem with the Aristotlelian teleology, the state is the highest form of development of society where individual potential can be achieved. As a precipitate of the social contract theory, the state performs some basic functions such as the protection of lives and property, harmonization of the ever conflicting interests of man, fair and equitable distribution of scarce resources and the promotion of the welfare of the citizens. The efficacious performance of these basic functions by the state can enhance peace and national development which is also dependent on the nature and character of the state. It is against this backdrop that the paper takes a critical look at peace and national development in Nigeria with particular reference to Rivers State within the purview of the nature and character of the Nigerian State.

\section{THEORETICAL FRAMEWORK}

Two theories were considered pertinent and adopted as analytical constructs. First is the Marxian Political Economy. One of the basic assumptions of Marxian Political Economy is that events or phenomena cannot be understood in isolation. But they can be understood in their relationship with other events or phenomena taking into consideration the intervening variables (Ryndina, Chernikov and Khudokormov, 1980) Marxian Political Economy also assumes the class character of the society within the view point of the social relations of production (Afanasyev, 1980). The appropriation of the surplus value by the capitalist has not only entrenched exploitation and inequality but also prepares the ground for revolutionary pressure and conflict.

Poverty and inequities promoted by the faulty distributive mechanism of state resources, opportunities and power are veritable sources of conflict. It should be noted that conflict can ensue in any social formation where 
exploitation, oppression, marginalization and injustice are perpetrated and perpetuated. A situation where what is socially produced or what may be referred to as common wealth is appropriated or plundered by one person or few persons is a hotbed for conflict which cannot guarantee peace needed for national development.

Second, is the Frustration-Aggression (F-A) theory which simply states that frustration leads to aggressive behaviour. According to Dollard et al (1939) as cited in Dennen (2005), "aggression is always a consequence of frustration". The Frustration-Aggression theory was propagated in 1939 by John Dollard, Leonard Doob, Ncal Miller, O.H. Mowrer and Robert Sears who were associates at the Yale University. Frustration sets in as encumbrances that impede goal attainment. The inability to achieve a goal invokes sense of frustration and the consequence is aggression. Every man is driven by the innate desire to survive and live a decent and fulfilled life. But when the sources of survival are threatened or frustrated, man does anything humanly possible to survive. Thus, frustration can lead to aggressive behaviour like violence, insurgency, electoral violence, conflict, militancy, agitation for secession, perpetration of social vices such as armed robbery, kidnapping, prostitution and indeed general insecurity. The exploitative, oppressive and repressive tendencies of not only the Nigerian state but also any hegemon can be frustrating and fuel conflict. Conflict which is the pursuit of incompatible goals is antithetical to peace and no development can take place without peace.

\section{UNDERSTANDING PEACE}

Peace is a sine qua non for the harmonization of interest which guarantees fruitful coexistence. The fruitful coexistence infuses an efficacious social order in the eco-socio-political systems necessary for National Development. Peace is seen as the converse of war and two interpretations are given in this regard. The instrumentalist interpretation sees peace as a means to an end. This means that peace is a necessary condition needed to achieve social progress and development (Ibeanu, 2006). On the other hand, the functionalist interpretation sees peace from a view point as playing a social function and from another perspective as the product of the function of other social structures. (Ibeanu, 2006). It follows that peace is the "Oil" that lubricates the social structures and it is in itself a product of the social structures.

Peace can also be conceptualized from the philosophical, sociological and political perspectives. From the philosophical point of view, many philosophers see peace as a natural, original, God-given state of human existence (Ibeanu, 2006). After all, God created man in His own image. Peace, therefore is a corruption-free status of man which approximates God's kingdom. Man in his natural state is good and peaceful but has become corrupted by human desire and greed. This unfortunate corrupted nature of man compelled Thomas Hobbes to see man in the state of nature as violent. The unregulated desire of man for felicity (that is protect his selfish interest) has placed man on a collision course with his fellow man. Thus, according to Thomas Hobbes, the state of nature is short, nasty and brutish - only the strongest survives. The fear of destruction in a violent and precarious state of nature forced man to enter into a social contract with a powerful force called the Leviathan. This social contract marked the genesis of the propagation of social contract theories and the subsequent emergence of the state which is needed to create a more peaceful and orderly society.

According to Ibeanu (2006), other philosophers such as the hedonists and utilitarians, suggest that human beings instinctively seek happiness and avoid pain. Consequently, they naturally prefer peace to war and violence. Moving away from relating peace to the original inclination and desires of human beings, Plato sees peace from the stand point of social context. He sees peace as a function of justice. For Plato, justice is giving to each his or her due. Plato divided the society into three groups - the workers, soldiers and the rulers (philosopher kings). For harmony and peace in society, each group must be placed in their functional areas in line with their natural endowment and capability. For instance, the workers should be concerned with the production of society's means of material existence, the soldiers should defend society while the knowledgeable, the philosopher king should rule. Injustice, according to Plato, occurs where this functional system is truncated. For instance where the philosopher king allow persons of appetite (worker) or courage (soldiers) to rule. In such a situation, there cannot be peace and social harmony.

Sociologically, peace is a condition where there is no social antagonism and individuals and groups are able to meet their needs and expectations (Ibeanu, 2006). This can be achieved from two approaches. The structural functionalism sees the social system as being made up parts or structures which are inter related and interdependent. These structures perform specific functions that sustain the social system, it follows that when structures perform their functions properly, there is order in society and infact, society inherently moves in the direction of order and stability supported by the requisite culture, norms and values which guarantee peace (Ibeanu, 
2006) Dialectical Materialism as postulated by the German Philosopher, Karl Marx considers the social relations of production and how what is socially produced is appropriated or distributed. For Karl Marx, society is divided into two classes - those who own the means of production (capitalist or dominant class) and those who do not own the means of production - (the proletariats or dominated and exploited class). The exploitation, domination and oppression finds expression in the appropriation of surplus value by the capitalist through the instrumentality of the state. The state and the class are therefore veritable instruments of exploitation and until they wither way, there will be no harmony and peace in society.

From the political view point, peace can be achieved when there is political order which finds expression in the institutionalization of political structures. There is therefore the need for order and stability in the society. There is need for participant political culture which enables the citizens to participate in the political system, especially with regard to the exercise of their political sovereignty. Again, government must rule with the interest of the people at heart and rationally and minimally employ the coercive apparatuses of the state. Peace will also mean the absence of domination of the under privileged and weak by the privileged and the powerful in society.

The above conceptualizations of peace seem to reflect the realities in Nigeria. Generally, peace is defined as the absence of war, fear, conflict, anxiety, suffering and violence. According to Francis (2006), peace is primarily concerned with creating and maintaining a just order in society and the resolution of conflict by nonviolent means.

It is instructive to note that peace can manifest in different forms, but basically, we have the inner peace and the outward or general peace. There is a general conception that peace is the absence of war. However, there appears to be what may be considered as inchoate reasoning that there can be peace even when there is war. This is not only deceptive but also a contradiction of sorts. Johan Galtung in Ibeanu (2006) alluded to the fact that war is only one form of violence, which is physical, open and direct. But there is another form of violence that is not immediately perceived as such. This has to do with social conditions such as poverty, exclusion, intimidation, oppression, want, fear and many types of psychological pressure (Ibeanu, 2006).

It then follows that if war is only one form of violence, which is physical, open and direct and there is another form of violence which finds expression in negative social conditions such as oppression, intimidation, poverty, exploitation, marginalization, the common denominator is violence. Violence in whatever form it comes cannot guarantee peace. This means that the later expression of violence (i.e. the aforementioned negative social conditions) which may not be conventional war not only accentuates but also perpetrates and perpetuates violence. No violent situation, whether conventional war or social conditions - induced - war can guarantee peace. People may be seen carrying out their normal legitimate activities, but there is no peace of the mind.

This is what probably instigated the philosopher, Rousseau to say that "Man is born free, but is seen everywhere in chains". What peace for instance can a poverty stricken man have when he is not sure of three square meal the next day or has been dispossessed of his property. For that poor man, he is in war and there can be no peace for him. It takes simple syllogism for us to understand that all wars whether conventional or unconventional are violent and cannot guarantee peace. Our contention, here is that war is war whether physical, direct and open or spiritual, indirect and hidden and there can be no peace in a war situation. It therefore logically follows that peace is the converse of war. It follows that beyond the well-orchestrated and intelligence driven military security architecture is also, and most importantly, the security of the social material existence of man. The elimination of the negative social conditions can improve on the social existence of man which in turn can curb conflict and facilitate peace necessary for National Development.

\section{NATIONAL DEVELOPMENT}

The Aristotelian teleology is consummated with the formation of state. The state through its government formulates and implements development policies and programmes. National development, therefore, is the effort made by the people through their government to improve their quality of life and ensure free and egalitarian society within the national boundary. According to Annang (2012), national development is seen as the sustainable improvement in both material and spiritual life of a nation, and which must be realizable in ways consistent with the protection of human dignity.

Lawal and Oluwatoyin (2011 see also Jaja Nwanegbo, and Odigbo. 2013), see national development as the overall development or a collective socio-economic, political as well as religious advancement of a country or nation. Aside from the economic aspect of national development which is facilitated by production, industrialization and accumulation of savings, the political aspect places premium on the role of the state as a controlling institution (Annang, 2012).

It is obvious that the state and its institutions should have the appropriate mix of human and material 
resources and ensure that what is produced is fairly and equitably distributed. National development can be seen with the purview of development indices like reduction or outright eradication of poverty, improvement in literacy, health services, housing condition and political awareness of the people. However, it should be noted that national development does not exist in a vacuum. It is hoisted on the strong pillars of rule of law and democracy in a political system. The political system should be orchestrated in such a way that it upholds the tenets of rule of law and democracy. Democracy not only at the level of institutional arrangement but more importantly, the internalization of democratic values, (Wonah, 2010). Democracy requires that the people participate in making decisions that affect their lives.

The participation of the people in the national development process underscores the people as change agents. Although these change agents can bring about positive or negative effects on national development depending on their level of civilization. It therefore, follows that what matters greatly in national development is the status and quality of life of the people. The need for improved human capacity building is being validated by the role of the people in national development.

There is therefore the need for the development of the human person. This view was corroborated by Martin Luther king Jr. when he said:

The prosperity of a country depend not on the abundance of its revenue nor on the strength of its fortification, not on the beauty of its public building but it consist in the number of cultivated citizens, its men of character and enlightenment.

On the contrary, national development cannot take place when the people are oppressed, intimidated, exploited, marginalized and are not equipped with right skills for positive change.

\section{THE STATE, PEACE AND NATIONAL DEVELOPMENT IN NIGERIA}

Thus, the state exists for the interest of the people and those who occupy state institutions must act in conformity with the "general will" of the people. However, it appears, the Nigerian state seems to have abdicated itself of the good traits of a state. The imposition of state by the colonial masters and the plural nature of Nigerian society are at the root of the political and socio-economic razzmatazz in Nigeria, the plurality of the Nigerian state aggravated by the fissiparous tendencies and subterfuge of the erstwhile colonial masters induced the 'labour' which unfortunately led to the delivery of the premature 'baby' called Nigeria. (Wonah, 2017).

The exploitative, repressive and oppressive tendencies of the colonial state were replicated and institutionalized by the post-colonial state in Nigeria. The political elites who were and are still intoxicated with power engaged in primitive accumulation as they saw and are still seeing the state and its apparatuses as veritable means of amassing wealth. Corruption with impunity became the order of the day and ascendancy to power became a do-or-die affair. Consequently, the electoral system is marred with electoral irregularities with the concomitant devastating electoral violence (Oddih, 2007), corruption which is a manifestation of a faulty distributive mechanism places more of the state resources in the hands of the elites while the majority of the people are marginalized and wallow in seemingly abysmal poverty and utter neglect. The above facts reflect the nature and character of Nigerian state which approximates politics in Nigeria.

The deliberate refusal of the actors of Nigerian State to invest adequately on economic ventures that would have multiplier effects on the economy explains not only the huge external debt burden but it has also plunged the country into devastating economic quagmire. This is aggravated by the brazen misappropriation and looting of public fund by the political elites. The payment of paltry sum as minimum wage and by extension as salaries to Nigerian workers in contrast with the huge allowances and salaries paid to political actors explain the faulty distributive mechanism. The faulty distributive mechanism is also reinforced by favoritism (man-knowman), ethnicity, nepotism and prebendalism. The implication is that it expands the chasm of inequality between the few rich and powerful and the rest of Nigerians.

Consequently, no society with such alarming inequality can be peaceful. Also worrisome is the refusal of governments at different levels to pay workers' entitlement except they go on strike, and payment of workers' salaries as and when due. More pathetic and criminal is the refusal to pay pensioners. The overall effect of the above negative social conditions is that it reproduces exploited, impoverished, oppressed, marginalize, disillusioned and dejected Nigerians. The majority of these impoverished and dejected Nigerians whose sources of livelihood have been threatened resort to social vices such as armed robbery, kidnapping, ritual killing, prostitution, human trafficking etc. These social anomalies serve as albatross to peace which in turn undermines national development in Nigeria.

In another perspective, the imposition of state and federation on the various ethnic groups in Nigeria by the erstwhile colonial masters reinforced fissiparous tendencies which led to 'marriage of inconvenience' as exemplified by the 1914 amalgamation. The effect is that issues that were supposed to be seen from the broad national perspective were and are still seen from the ethnic point of view. The resultant asymmetrical power structure perpetrates the exclusion, alienation, marginalization of some of the ethnic groups. It robs the people the 
sense of belonging and ultimately prepares the ground for separatist agitation. According to Wonah (2016), Politics of exclusion can be seen also as a form social exclusion which is a multi-dimensional process of progressive social rupture, detaching groups and individuals from social relations and institutions and preventing them from full participation in the normal, normatively prescribed activities of the society in which they live.

It follows that the promulgation of the obnoxious land Use Act, the attendant refusal to allow the states to control their resource (especially when oil was found in the minority region and became the major source of revenue), the scuttling of the autonomy of the other tiers of government, particularly local government, and the concentration of power at the centre, not only explains the pseudo federalism practised in Nigeria but also encumbers good governance and waters the ground for conflict to thrive in Nigeria.

In the discourse of peace, conflict and security are indispensible. Whereas, there can be no peace in the midst of conflict or violence, there is therefore the need to secure peace. Thus, securitization of peace is about providing the enabling conditions that can guarantee peace. Security generally is about the condition or feeling safe from harm or danger, the defence, protection and preservation of core values, and the absence of threats to acquire values (Francis, 2008). Aside from the fact that security can be seen as the well thought-out and orchestrated military arrangements and intelligence, security can also be seen, and most importantly, as the protection, preservation and recreation of those conditions or resources necessary for human survival and existence. If for instance, the state does not protect the environment from anthropogenic activities; the environment in what may look like reprisal attack fights back in the form of global warming, leading to climate change, flood, desertification and other environmental perturbations. This can lead to food security as farmlands are submerged by flood, and 'land squeeze' which are breeding grounds for conflict.

According to Oladiran (2014), security means safety or freedom from danger; and protection from external attack or infiltration. The point here is that beyond the protection of lives and property is the fact that security also means the protection against the ravages of the negative social conditions which rob man of the much needed peace necessary for development. This view was corroborated by Ogunbanwo as cited in Oladiran, (2014; P.51) when he aptly noted that

Security is more than military security or security from external attacks. For many of the four billion inhabitants in the developing countries, security is conceived as the basic level of the struggle for survival. Therefore, in order to provide an integrated African security assessment, the non-military dimensions of security should be added. Hence forth, African security as concept should be applied in its broadest sense to include economic security, social security and technological security.

In concurring with the overarching view about security, MCNamara as cited in Oladiran, (2014; P.51) observed that

Any society that seeks to achieve adequate military security against the background of acute food shortage, population explosion, low level of production, and per capita income, low technological development, inadequate and efficient public utilities, and chronic problem of unemployment, has a false sense of security.

In their view, Gambo and Kwaja, (2010:47) noted that National Security also means the ability of the state to function effectively so that it is able to serve its interest and those of its citizens. Summarily, National Security is the totality of the security architecture of a country designed to protect not only lives and property, the territorial integrity but also the objective social conditions which are encapsulated in the National interests of the country. With the protection of lives and property, territorial integrity and the objective social conditions, National Security engenders peace which is necessary for national development in any society.

However, due to the exploitative, oppressive and fissiparous tendencies that characterize the Nigerian State, such negative social conditions like exploitation, poverty, hunger, marginalization, environmental degradation and unemployment render national security impotent in facilitating peace which is necessary for national development. For instance, the national bureau of statistics noted that the unemployment rate in Nigeria increased to 18.90 percent in the third quarter of 2017. Unemployment rate in Nigeria averaged 10.63 percent from 2006 until 2017, reaching an all-time high of 19.70 percent in the forth quarter of 2009 and a record low of 5.10 percent in the forth quarter of 2010 (https://trading economics.com/Nigeria/unemployment -rate). This means that a good number of Nigerians are unemployed and their sources of livelihood are seriously threatened.

Consequently, criminal activities such as armed robbery, kidnapping, prostitution, human trafficking, corruption and ritual killing are on the increase in Nigeria. These negative social conditions are harbingers of conflict which undermine peace and national development. Unfortunately, Nigerian State seems to have ignored 
the root cause of conflict and general insecurity by its outright refusal to secure the sources of livelihood for Nigerians. Instead, it prefers addressing the symptoms by allocating huge budgetary estimates to defence and internal security with little or nothing to show for it. Security vote and ecological fund allocations have been privatized as most political leaders misappropriate them and divert them for their selfish interests. In fact, most political leaders in Nigeria seem to be fishing in a troubled sea by taking advantage of the conflict and general insecurity in Nigeria to enrich themselves. The Dasuki gate scandal is a pointer in this regard.

It should be noted that the exploitative, oppressive and divisive tendencies of Nigerian State are also replicated in the State, local government areas, communities and even in the families. Some people, due to their position in Government or their wealth (sometimes ill - gotten wealth) exploit, oppress their people and perpetrate injustice in their communities or families. They plunder other people's land and truncate and divert the course of traditional chieftaincy institutions. The indiscriminate appointment and recognition of chiefs and Ezes without due process and respect for the tradition and conventions of the people is not only sacrilegious but also a veritable source of conflict in the communities.

Perhaps, the most pathetic and more devastating is the fact that most politicians in their unbridled quest and inordinate ambition to acquire political power and remain perpetually in office, even against the wish of the electorates, hire thugs and arm them. These thugs have metamorphosed into deadly rival cult groups and most communities are flooded with the blood of human beings. These communities are deserted and the 'Landlords' are now in charge. In these communities, farmlands, rivers and creeks are abandoned which adversely affects the sources of livelihood of the people and reinforce hunger and poverty in the land. These youths who are cult members would have been gainfully engaged in productive ventures but they are patronized by some politicians and it appears might is now right. Also alarming is the fact that due to pecuniary gains and other selfish interests, most traditional rulers are now obviously partisan, thereby desecrating the sacred traditional institution and fanning the embers of discord and conflict in the communities.

\section{PEACE AND DEVELOPMENT IN RIVERS STATE}

Rivers State is one of the thirty-six (36) States in Nigeria. It is christened as the "Treasure base of the nation". This 'Christian' name is a reflection of the huge mineral resources (particularly crude oil and gas) and other resources deposited in the land. In fact, Rivers State is blessed with human and material resources. Rivers State is a part of the larger Nigerian State and its political system. Every system has parts that are inter-related and interdependent. The system is sustained by the functionality of the parts. This means that anything that happens to one part would invariably affect the other parts and indeed the entire system.

By this simple system analysis, it follows that the exploitative, oppressive, marginalizing and divisive tendencies of the Nigerian State are also replicated in Rivers State and they adversely affect peace and development in Rivers State. Before now, Rivers State used to be a peaceful State in the Niger Delta Region where residents slept with their two eyes closed. But unfortunately, it appears the reverse is the case now. It follows, that those negative social conditions threatening the peace of Nigeria and national development are also prevalent in Rivers State. For instance, the exploration and exploitation of crude oil in Rivers State and indeed the entire Niger Delta Region, degraded the environment with its attendant environmental perturbations which threatened the sources of livelihood of the people, thereby reinforcing poverty and hunger.

The promulgation of the land Use Act by the Nigerian State, in what appears like 'constitutional robbery' 'stole' the mineral resources-crude oil from Rivers State. The selfish, discriminatory and centralized allocation of the proceeds of oil through the so called federation account propagated and intensified the struggle for resource control. The use of coercive apparatuses of the state by the Nigerian state to suppress the agitation for resource control led to conflict and general insecurity in the Niger Delta Region. The oil bunkering and the artisanal refining of crude oil are major sources of insecurity and environmental pollution in Rivers State. The life-threatening soot in Rivers State is a clear example.

Apart from the lazy mentality which crude oil has infused into the generality of the people, to the extent that farmlands, rivers and creeks have been abandoned, the politics of oil is also a major source of conflict in some oil bearing communities in Rivers State. Some indigenes of the communities who are landlords or contractors to the Multinational Oil Companies only protect their selfish interest at the expense of the entire community. In most cases, they hinder the successful implementation of Memorandum of Understanding (MOU) between the $\mathrm{MNOC}_{S}$ and the Community, and they do not want any other person to benefit from the activities of the MNOC. Again is the fact that the $\mathrm{MNOC}_{\mathrm{S}}$ in their usual manner also deliberately adopt divide-and- rule tactics and plunge the community into conflict.

The other cases earlier mentioned about greedy politicians and powerful individuals in the communities, partisan traditional rulers and cultism are also prevalent in Rivers State. Regrettably, virtually all the communities in Rivers State are asphyxiating in one conflict or the other. In some communities, there is what looks like uneasy calm but beneath the surface there is conflict. Another fact is that our political leaders in Rivers State play politics of bitterness, acrimony and rancor. These conditions have plunged Rivers State into the dungeon of conflict which 
erodes peace and undermine development in Rivers State. It may be a surprise to know that some months ago, Rivers State was rated as the State with highest misery index. Paradoxically, this is the State known as the treasure base of the nation. The questions that seem to boggle the mind now are - where is the treasure and why are some community in Rivers State still exist as if they are in the dark ages?

\section{THE WAY FORWARD}

It is a popular belief, particularly in Research that when you identify a problem, the problem is half solved. This means that you can aptly proffer solution when you know the problem. From the foregoing, it is obvious that the threat to peace emanates mainly from the nature and character of the Nigerian State. The exploitative, oppressive, marginalizing and divisive tendencies of Nigeria State are attributable to the utter disregard of democratic culture. There is therefore the need for democratic institutions to be strengthened and democratic culture imbibed and demonstrated by Nigerians particularly, the political leaders.

Consequently, democratic values such as accountability, transparency, fairness, tolerance, social justice, equity and rule of law must be upheld. Again is the fact that the faulty distributive mechanism that places the scarce resources or what may be referred to as the "common wealth" in the hands of few individuals should be corrected to ensure fair and equitable distribution of the scarce resources. The various processes of facilitating peace such as arbitration, mediation, conciliation and other means of Alternative Dispute Resolution (ADR) must be reinvigorated.

Also the Nigerian State should review and vigorously implement environmental policies and rejuvenate relevant institutions in order to regulate anthropogenic activities and protect the environment. Traditional chieftaincy institutions should be respected and traditional rulers should avoid partisanship. Fundamentally, there should be increased investment in economic activities, particularly agro-based business that have multiplier effect. For instance, Rivers State should revive Risonpalm, Pabod breweries and other companies which can create employment opportunities for Rivers State indigenes. When the people, especially the youths are gainfully engaged in productive ventures, it will drastically reduce crime, violence and general insecurity. This will attract investors, as no investor would invest in a precarious atmosphere of crime, violence and general insecurity. Elective Public Offices should be made less attractive. This will reduce overall recurrent expenditure and make more fund available for capital projects which will have direct bearing on the living conditions of the people. It will also discourage politicians from seeing politics as a do-or-die affair. And as a consequence, it discourages their patronage for cultism. The fight against corruption should be intensified, comprehensive and there should be no sacred cow. The change begins with you program of the present administration should be intensified and be made a national value. Above all, we should not only be apostles of peace but also live peaceful life devoid of greed, envy, corruption, acrimony, bitterness and rancor in our families, communities, Rivers State and Nigeria at large.

\section{CONCLUDING REMARKS}

Peace is a necessary condition for national development to thrive. Security is needed for peace to reign. Security therefore needs to be reinforced. And security is not only from the military perspective but more importantly, from the purview of securing the sources of livelihood of the people. This would reduce conflict and enthrone peace which is necessary for national development. Unfortunately, due to the nature and character of the Nigerian State the negative social conditions that fuel conflict are prevalent. These negative- conditions are also replicated in Rivers State as a part of the larger Nigerian political system. Consequently, peace is threatened in Rivers State which is also undermining development in Rivers State. There is therefore the need to eliminate or curb those negative social conditions that foster conflict which would secure peace for national development in Rivers State and Nigeria. 


\section{REFERENCES}

Afanasyev, V.G. (1980). Marxist-Philosophy. Moscow. Progress publishers.

Annang, A. (2012). National Development in Nigeria: The Elitist Role. In African Journal of Culture, Philosophy and Society. (http://www.aworomannang.com/new). (online) accessed $27^{\text {th }}$ February, 2016).

Dennen, J.M.G. (2006). Theories of Aggression. Default Journal University of Groningen. www.mg.n1/research/portal/files. accessed on 4/7/17.

Francis, D.J. (2006) Peace and Conflict Studies: An African Overview of Basic Concepts. In Introduction to Peace and Conflict Studies in West Africa: A Reader. Shedrack Gaya Best (ed). Ibadan. Spectrum Books Limited.

https://tradingeconomics.com/nigeria/unemployment-rate.

Ibeanu, O. (2006). Conceptualizing Peace. In Introduction to Peace and Conflict Studies in West Africa: A Research. Ibadan. Spectrum Books Limited.

Lawal, T. and Oluwatoyin, A. (2011). National Development in Nigeria: Issues, Challenges and Prospects. In Journal of Public Administration and Policy Research Vol. 3(9) pp. 237-241, November, 2011 (http://www.academicjournals.org/jpaper) (online) Accessed on $27^{\text {th }}$ February, 2016.

Nwanegbo, J. C. and Odigbo, J. (2013). Security and National Development in Nigeia: The Threat of Boko Haram. In International Journal of Humanities and Social Sciences vol. 3 No. 4 (Special issues - February 2013/29.pdf) (online) (accessed 27 $7^{\text {th }}$ February, 2016).

Oladiran, A. (2014). Security Challenges and Development in Nigeria: Leadership to the Rescue? In International Journal of Academic Research in Public Policy and Governance. January, 2014, vol. 1. No. 3 (mgrs.com/---./security_challengeand-development in Nigeria_leadership_to_the (Accessed on 6/7/17).

Ryndina, Chernikov, Khudokormov, (1980). Political Economy. Moscow. Progress Publishers.

Wonah E.I. (2010). "Party Ideoology, Campaign and Consolidation of Democracy in Nigeria." In Political Community and Nigerian Democracy; A Book of Reading. Godwin B. Okon and Aniefiok Udoudo (eds).

Wonah, E. I. (2016). Politics of Exclusion and Violence in Nigeria”. in African Conflict Profile Volume 2, Number 3, November, 2016: pp 111 - 120. A Journal of the Centre for Conflict and Gender Studies (CCGS), University of Port Harcourt, Port Harcourt.

Wonah, E. I. (2017). Domestic Terrorism and National Development in Nigeria: Unmasking the Real Terrorist. In Developing Country Studies vol. 7, No 2, 2017 pp. 74 - 79. 